\title{
Designing a synchrotron micro-focusing beamline for macromolecular crystallography
}

\begin{abstract}
$\mathbf{A}^{\mathrm{f}}$ fter a successful 10 years of operation, the Canadian Macromolecular Crystallography Facility 08ID-1 beamline will undergo an upgrade to establish micro-beam capability. This paper is mostly focussed on optics and computer simulations for ray tracing of the beamline. After completion, the focussed beam at the sample will have a much smaller size of $50 \times 5 \mu \mathrm{m}^{2}(\mathrm{H} \times \mathrm{V})$, allowing measurement of X-ray diffraction patterns from much smaller crystals than possible presently. The beamline will be equipped with a fast sample changer and an ultra-low noise photon counting detector, allowing shutter-less operation of the beamline. Additionally, it will be possible to perform in-situ room-temperature experiments.
\end{abstract}

\section{INTRODUCTION}

The Canadian Light Source Inc. (CLSI) is a $2.9 \mathrm{GeV}$ synchrotron ring operating at $250 \mathrm{~mA}$, located on the campus of the University of Saskatchewan. The CMCF operates two beamlines, 08ID-1 and 08B1-1 [2, 3, cmcf.lightsource.ca]. Together these beamlines enable high-resolution structural studies of proteins, nucleic acids and other macromolecules, satisfying the requirements of the most challenging and diverse crystallographic experiments. When the CMCF 08ID-1 beamline was designed $\sim 13$ years ago, small macromolecular crystals were considered to have the size of 50-100 $\mu \mathrm{m}$. Over the last decade, the new synchrotron designs and improved $\mathrm{X}$-ray optics components allow recording diffraction patterns from crystals having dimensions as small as 1-5 $\mu \mathrm{m}$. This was possible due to more intense X-ray sources with flux $>10^{11}$ photons / s focused to an area of $\sim 5$ $\mu \mathrm{m}$ diameters or less. The proposed upgrade of the 08ID-1 beamline at the CLS will allow the attainment of similar parameters.

Structural biology is a branch of molecular biology, biochemistry and biophysics concerned with the atomic structure of biological macromolecules, especially proteins and nucleic acids, addressing the questions of how the three-dimensional structure of macromolecules relates to their biological roles. Over the last $\sim 50$ years there has been tremendous progress in both the instrumentation for capturing the diffraction from macromolecular crystals as well as methodology for deriving the atomic structure from the experimental X-ray diffraction pattern. It is important to mention that one of the pioneers in the use of synchrotron radiation in structural biology was Alexander Wlodawer, who performed the groundbreaking experiments at beamline BL1-4 at Stanford [1]. Despite many advances, current and future challenges in structural biology are nevertheless daunting. Only a fraction of the estimated $\sim 30,000$ human proteins are structurally characterized. Particularly underrepresented are large protein complexes and membrane proteins, yet they play key roles in most biological processes. Advancement in structure determination of these most challenging macromolecular complexes will require further technological improvement and continuing progress. This includes expression and crystallization of membrane proteins as well as development of suitable synchrotron beamlines to study very small crystals. Recent successes are only the beginning, as membrane-bound proteins are prime drug targets for pharmaceutical interventions. In the drug discovery case, the goal is to use structures of proteins (drug targets) and protein-ligand complexes to directly and efficiently optimize lead compounds and to convert them to drug candidates. This process is called structure-based drug design. The Canadian Macromolecular Crystallography Facility (CMCF) plays an important role in this process. The $\mathrm{CMCF}$ is a truly national facility that supports more than $80 \%$ of Canadian macromolecular crystallography laboratories. Since the beginning of its operation 10 years ago, more than 400 peer reviewed papers have been published with data collected at the CMCF and $\sim 750$ structures deposited in the Protein Data Bank (Fig. 1).

\section{Pawel Grochulski ${ }^{1,2, \square}$}

\section{Miroslaw Cygler ${ }^{3}$}

\section{Brian Yates ${ }^{1}$}

${ }^{1}$ Canadian Light Source Inc., 44 Innovation Boulevard, Saskatoon, SK S7N 2V3, Canada ${ }^{2}$ College of Pharmacy and Nutrition, University of Saskatchewan, SK S7N 5C9, Canada ${ }^{3}$ Department of Biochemistry, University of Saskatchewan, Saskatoon, SK S7N 5E5, Canada

Canadian Light Source Inc., 44 Innovation Boulevard, Saskatoon, SK S7N 2V3, Canada e-mail: pawel.grochulski@lightsource.ca

Received: June 2, 2016

Accepted: July 7, 2016

Key words: synchrotron radiation, structural biology, X-ray optics, synchrotron instrumentation, macromolecular crystallography beamline

Abbreviations: CFI - Canadian Foundation for Innovation; CMCF - Canadian Macromolecular Crystallography Facility; SGU - small-gap in-vacuum undulator; DCM - double crystal monochromator; VFM - vertically focusing mirror; HFM - horizontally focusing mirror; $\mu \mathrm{VFM}$ - micro vertically focusing mirror; RMS - root-mean-square

Acknowledgements: The Canadian Light Source is supported by the Canada Foundation for Innovation, Natural Sciences and Engineering Research Council of Canada, the University of Saskatchewan, the Government of Saskatchewan, Western Economic Diversification Canada, the National Research Council Canada, and the Canadian Institutes of Health Research The authors would like to thank the co-applicants of the CFI proposal, Alisdair Boraston, University of Victoria, Mark Glover, University of Alberta, Alba Guarne, McMaster University, Zongchao Jia, Queen's University, Brian Mark, University of Manitoba, Bhushan Nagar, McGill University, Kenneth $\mathrm{Ng}$, University of Calgary, Emil Pai, University of Toronto and Filip Van Petegem, University of British Columbia as well as the CLSI staff; Michel Fodje, Shaun Labiuk, James Gorin, Kathryn Janzen, Drew Bertwistle and Shawn Carriere. 


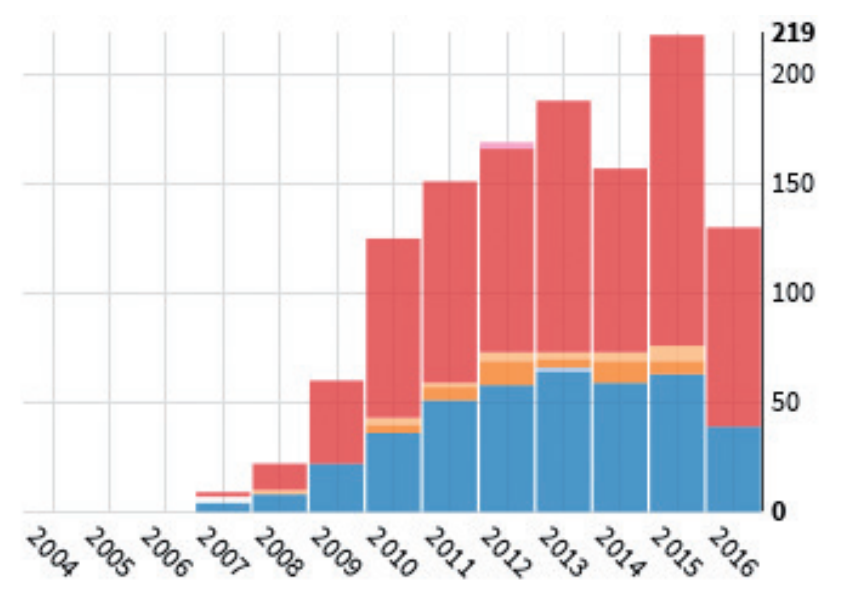

Figure 1. CMCF activity summary (number of publications by year, including: peer-reviewed articles (blue), conference proceedings (light blue), doctoral theses (orange), masters theses (light orange), magazine articles (green), book/chapter sections (light green), PDB depositions (red) and patents (pink)).

Rapid scanning of multiple crystals requires fast, reliable and versatile sample changers, key to high-throughput screening of numerous crystals, either in search for the best diffracting crystal or for rapidly collecting diffraction data from a series of protein crystals containing small drug molecules (potential inhibitors or modulators). Obtaining large, well diffracting crystals is currently the major bottleneck in macromolecular crystallography and much effort is being directed toward obtaining useful diffraction data from smaller and smaller crystals and extracting useful information from crystals of lower quality. Much effort in numerous individual research labs is dedicated toward improving sample isolation, preparation and crystallization techniques. Simultaneously, much effort is focused on advancement of synchrotron facilities, including: focusing X-ray beams to a few microns with very low divergence, and developing very sensitive, ultra-low-noise $\mathrm{X}$-ray detectors with large dynamic range. Increasing the signal-tonoise ratio is essential for detection and measurement of weak anomalous signal, which is crucial to 'de novo' crystal structure determination.

The key to increasing the intensity of the 08ID-1 beamline is installation of a new $3.82 \mathrm{~m}$ long small-gap in-vacuum undulator (SGU). To accommodate the higher heat loads generated by the new SGU and to focus the X-rays more tightly with high spatial and temporal stability, the existing X-ray optical elements will be replaced or modified and new ones will be added. In the end-station, a five-axis alignment table will improve alignment of small samples with the micro-beam. The upgrade will include a new, high-efficiency robotic sample-changer and an ultra-low-noise solid-state X-ray detector with minimal total dead time. These hardware changes will bring the 08ID-1 beamline on par with the highest world-class standards.

\section{BEAMLINE OPTICS AND SHADOW SIMULATIONS}

The new specifications of the 08ID-1 beamline are compared to the current specifications in Table 1, and the layout of the new beamline design is shown in figure 2 . The advancement of beamlines for macromolecular crystallography experiments is measured in higher brilliance; characterized by a smaller beam size, smaller beam divergence and higher photon flux density. Brilliance of a beamline can be increased by increasing the length of the small-gap in-vacuum undulator (SGU) or by lowering the electron beam emittance. Lowering the emittance of

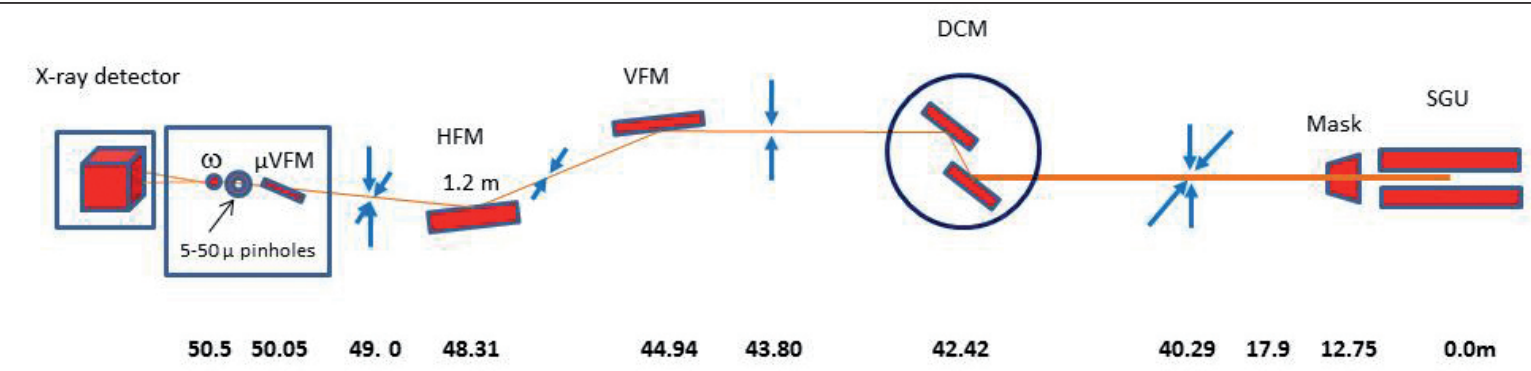

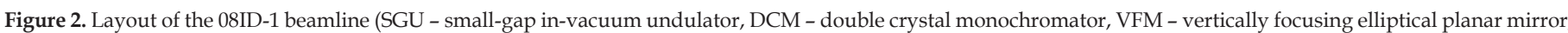

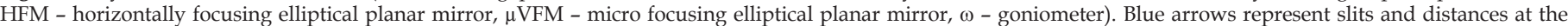
bottom indicate positions of the components from the source.

Table 1. Specifications of the 08ID-1 beamline.

\begin{tabular}{|c|c|c|c|}
\hline & Current (250 mA) & Upgraded (500 mA) & Examples of current best worldwide \\
\hline Spectral range & $6.5-18.0 \mathrm{keV}$ & $5.0-20.0 \mathrm{keV}$ & $4-35 \mathrm{keV}[4]$ \\
\hline $\begin{array}{l}\text { Energy bandwidth }(\Delta \mathrm{E} / \mathrm{E}) \\
(\mathrm{Si}(111) \text { at } 12 \mathrm{keV})\end{array}$ & $1.5 \times 10^{-4}$ & $1.5 \times 10^{-4}$ & $\sim 1.5 \times 10^{-4}[5]$ \\
\hline $\begin{array}{l}\text { Flux on the sample @ } \\
12 \mathrm{keV} \text { (photons } / \mathrm{s})^{*}\end{array}$ & $\begin{array}{l}2 \times 10^{12}(100 \mu \mathrm{m}) \\
1 \times 10^{12}(50 \mu \mathrm{m}) \\
5 \times 10^{11}(20 \mu \mathrm{m}) \\
2 \times 10^{10}(5 \mu \mathrm{m})\end{array}$ & $\begin{array}{l}>10^{13} \\
>10^{13}(50 \mu \mathrm{m}) \\
>10^{12}(20 \mu \mathrm{m}) \\
>10^{11}(5 \mu \mathrm{m})\end{array}$ & $\begin{array}{l}5 \times 10^{12}\left(5 \times 5 \mu \mathrm{m}^{2}\right) \text { 23ID-D (APS) [6]; }>10^{12}(3-100 \\
\left.\mu \mathrm{m}^{2}\right) \text { ID24 (DIAMOND) [7]; } 5.4 \times 10^{12}\left(10 \times 10 \mu \mathrm{m}^{2}\right) \\
\text { BL32XU (Spring8) [8]; } 10^{12}(8 \mu \mathrm{m}) \text { ID23-2 (ESRF) [9] }\end{array}$ \\
\hline Focal Size @ $12 \mathrm{keV}[\mu \mathrm{m} \times \mu \mathrm{m}]$ & $150(\mathrm{H}) \times 30(\mathrm{~V})$ & $50(\mathrm{H}) \times 5(\mathrm{~V})$ & Range $1-50(\mathrm{H}) \times 1-50(\mathrm{~V})[4]$ \\
\hline $\begin{array}{l}\text { Beam crossfire at the sample } \\
\text { (mrad×mrad)@ } 12 \mathrm{keV}\end{array}$ & $0.9(\mathrm{H}) \times 0.2(\mathrm{~V})$ & $1.6(\mathrm{H}) \times 0.4(\mathrm{~V})$ (no pinhole) & $<1.5[4]$ \\
\hline
\end{tabular}

*The beam sizes are given in parentheses 


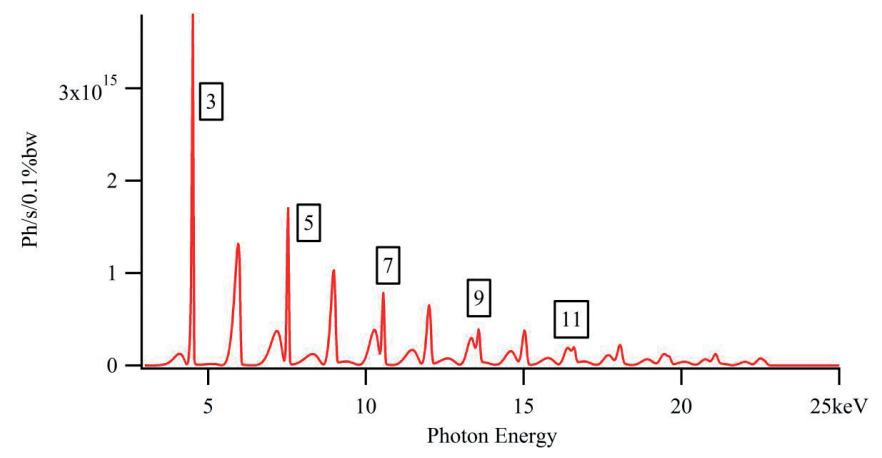

Figure 3. Spectral flux of a $3.82 \mathrm{~m} \mathrm{SGU}$ with a period of $20 \mathrm{~mm}$ for $\mathrm{k}_{\text {eff }}=1.82$ (SRW [11]). Ring operation at $500 \mathrm{~mA}$.

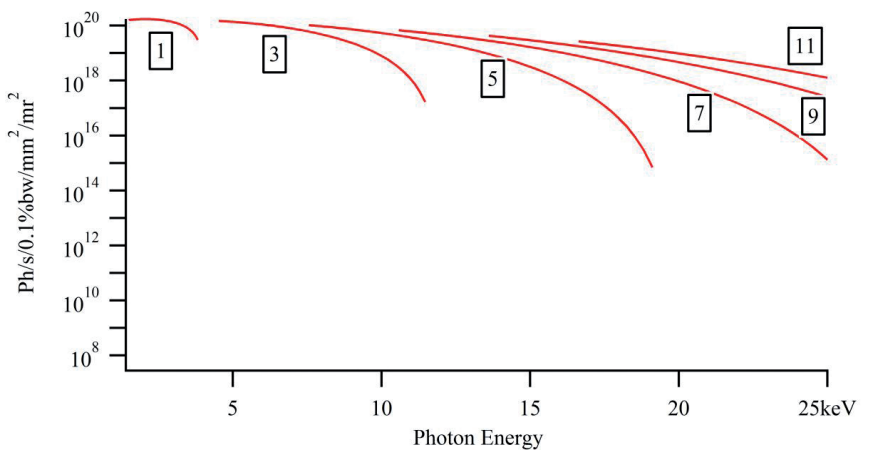

Figure 4. Estimated brilliance of a $3.82 \mathrm{~m}$ SGU with a period of $20 \mathrm{~mm}$ at a $5.2 \mathrm{~mm}$ gap. To cover the designed photon range, harmonics from 3 to 11 will be used (SRW [11]). Ring operation at $500 \mathrm{~mA}$.

the CLS ring from the current $18 \mathrm{~nm}$-rad, would require major changes to the ring lattice and is not in the plans. Therefore, we

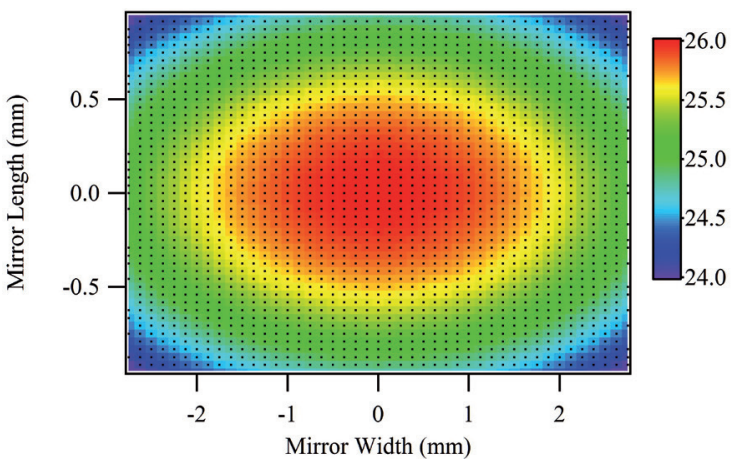

Figure 5. Power density $\left(\mathrm{W} / \mathrm{mm}^{2}\right)$ on the first crystal of the DCM when it is orthogonal to the beam [10]. Calculations performed with the low energy diamond filter $(400 \mu \mathrm{m})$ in the path. Calculations used the worst-case scenario of high-tune mode with $0.1 \%$ coupling, center of the straight geometry for the insertion device, and $500 \mathrm{~mA}$ ring operation.

exploit the first option by increasing the length of the SGU to $3.82 \mathrm{~m}$, the maximum value possible within the straight section of the CLS ring. The SGU will be a hybrid undulator with a periodic length of $20 \mathrm{~mm}$ and a total power of $11.43 \mathrm{~kW}$ [10, $500 \mathrm{~mA}$ ring operation]. The spectral flux is shown on figure 3. The estimated brilliance of the new SGU for the same range of photon energies with a peak field of $1.06 \mathrm{~T}$ at $5.2 \mathrm{~mm}$ gap is shown in figure 4 . The spectral flux produced by such a SGU can be calculated using the SRW program [11]. For example, the spectral flux at $12.0 \mathrm{keV}$ calculated for the $8^{\text {th }}$ harmonic is equal to $\sim 6.3 \times 10^{14}[\mathrm{ph} / \mathrm{s} / 0.1 \% \mathrm{bw}$ ] (Fig. 3). For a double crystal monochromator (DCM) equipped with cryogenically-cooled Si (111) crystals, an energy bandwidth of $1.5 \times 10^{-4}$ can be achieved which corresponds to a calculated photon flux of $9.0 \times 10^{13}[\mathrm{ph} / \mathrm{s}]$. The DCM is followed by three mirrors, and taking their reflectivity into account, the final flux at the sample will be lower, depending on the photon energy (Tab. 1).

Table 2. The mirrors and their basic parameters.

\begin{tabular}{|c|c|c|c|c|c|}
\hline Mirror & Purpose & Length $[\mathrm{m}]$ & $\begin{array}{l}\text { Slope error } \\
\text { [ } \mu \text { rad RMS] }\end{array}$ & $\begin{array}{l}\text { Grazing angle } \\
\text { [mrad] }\end{array}$ & $\begin{array}{l}\text { Coating, two } \\
\text { stripes }\end{array}$ \\
\hline $\begin{array}{l}\text { VFM (elliptical planar } \\
\text { with adaptive benders) }\end{array}$ & $\begin{array}{l}\text { Refocuses the light vertically from the } \\
\text { undulator to the secondary focus. }\end{array}$ & $>0.35$ & $<0.5$ & 3.9 & Rh and Ir \\
\hline HFM (elliptical planar) & $\begin{array}{l}\text { Refocuses the light horizontally from } \\
\text { the undulator to the crystal sample. }\end{array}$ & 1.2 & $<1.0$ & 3.9 & Rh and Ir \\
\hline $\begin{array}{l}\mu V F M \text { (elliptical planar } \\
\text { with adaptive benders) }\end{array}$ & $\begin{array}{l}\text { Refocuses vertically the secondary } \\
\text { focus light to the crystal sample. }\end{array}$ & 0.2 & $<1.0$ & 3.9 & Rh and Ir \\
\hline
\end{tabular}

Rh $30 . \mathrm{nm}$ on $\mathrm{SiO} 2$ at $0.22345 \mathrm{deg}, \mathrm{P}=0$.

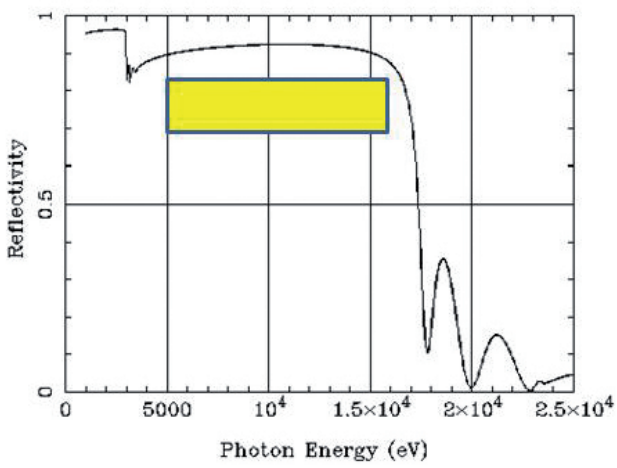

Ir $30 . \mathrm{nm}$ on SiO2 at $0.22345 \mathrm{deg}, \mathrm{P}=0$.

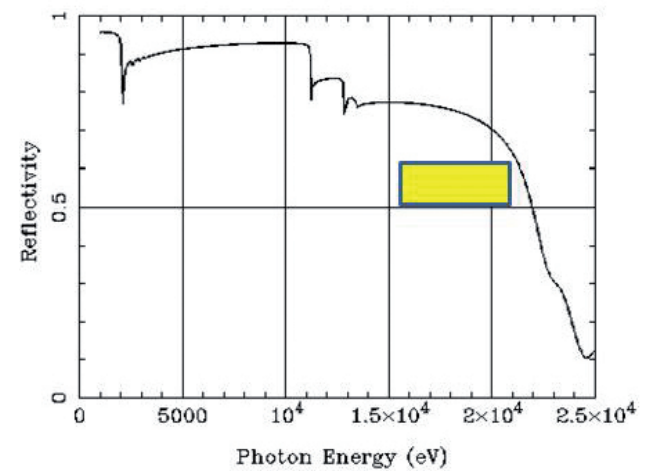

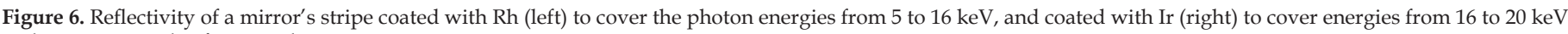
at the grazing angle of 3.9 mrad. 
a
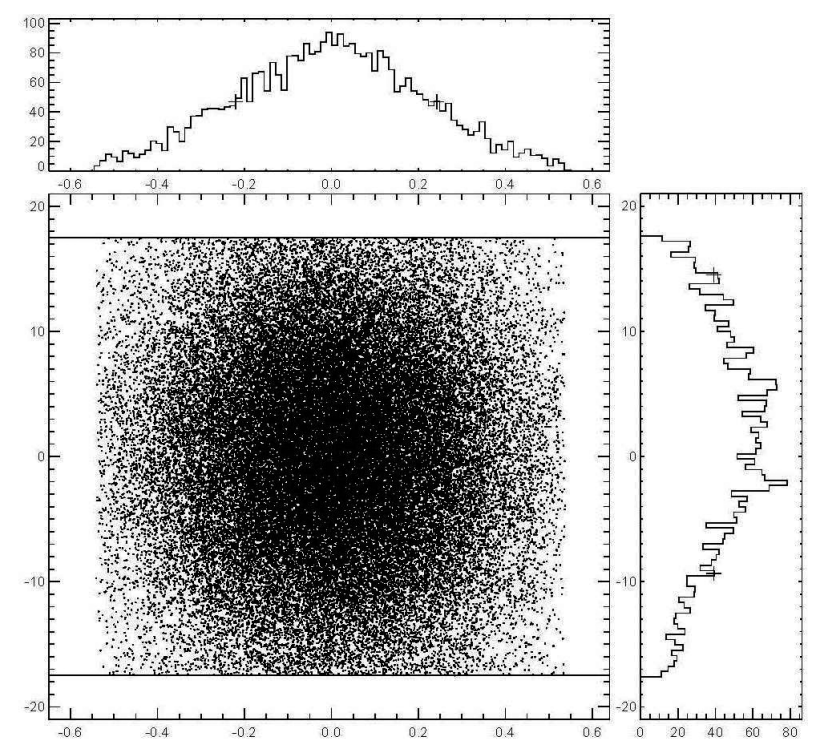

$\mathrm{b}$
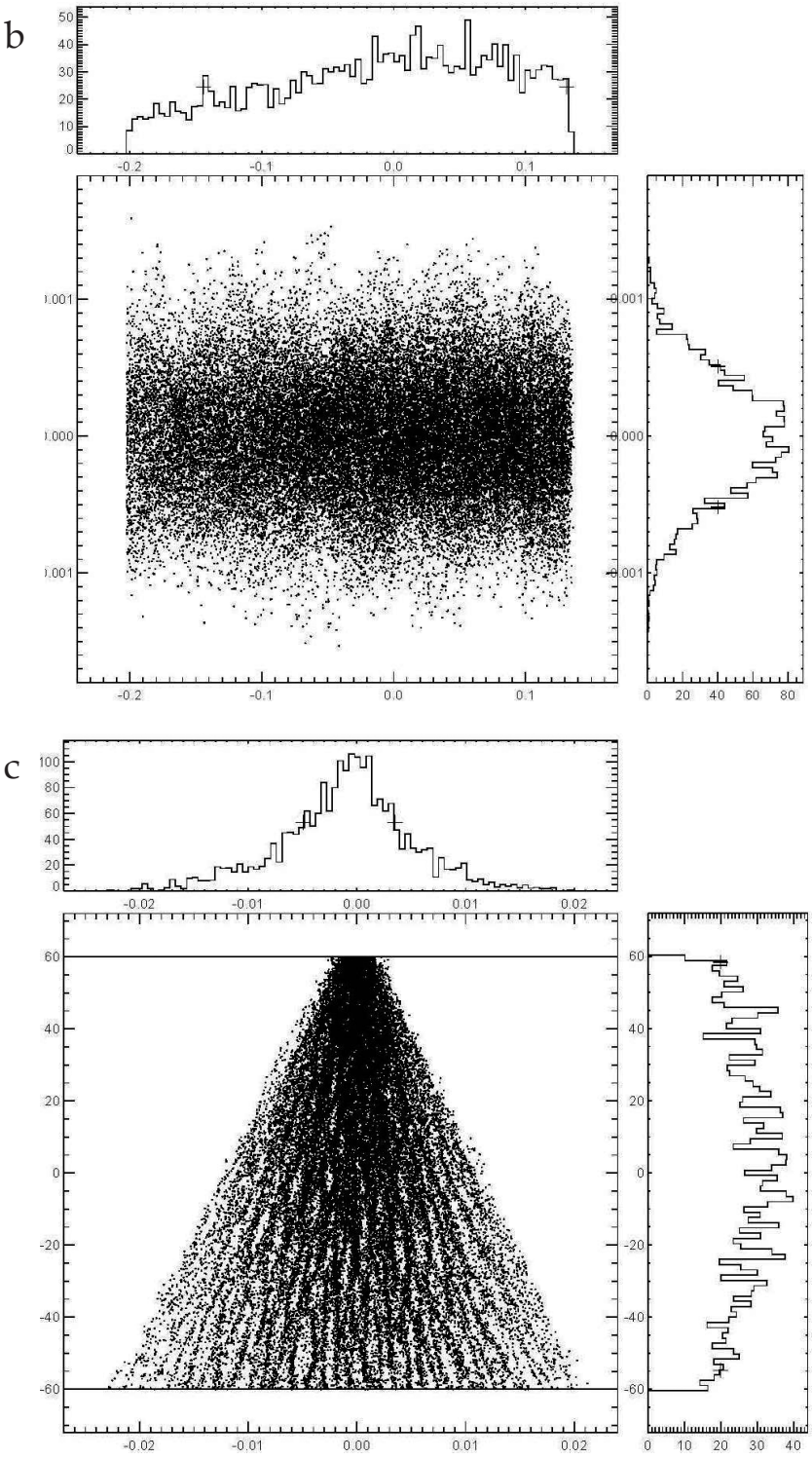

d

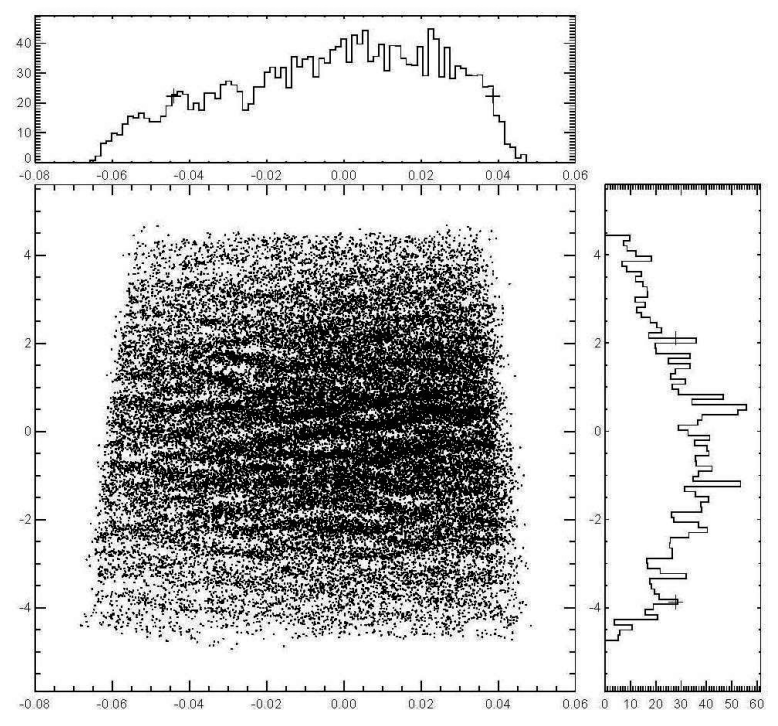

e
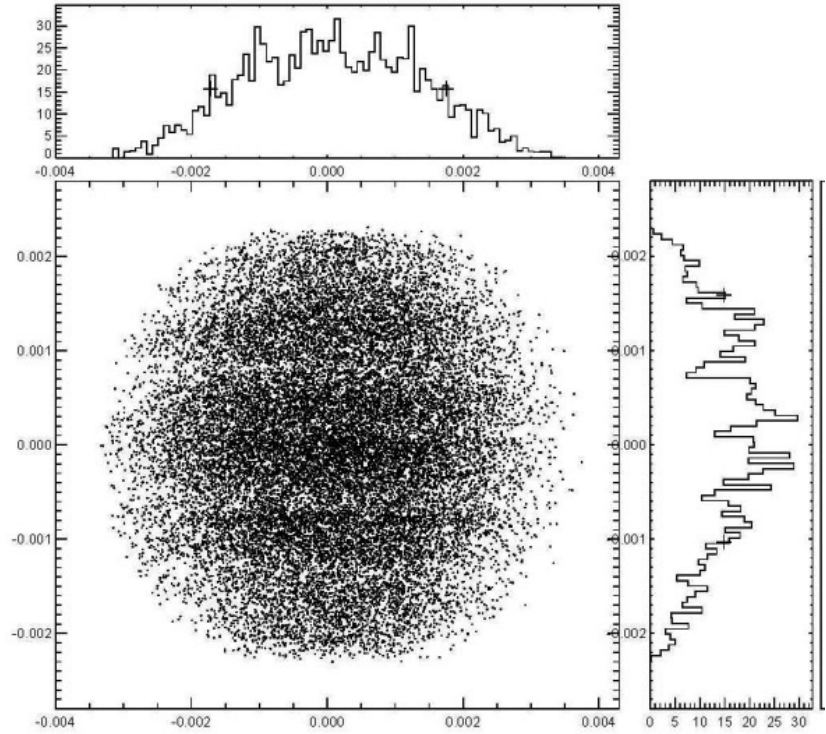

f
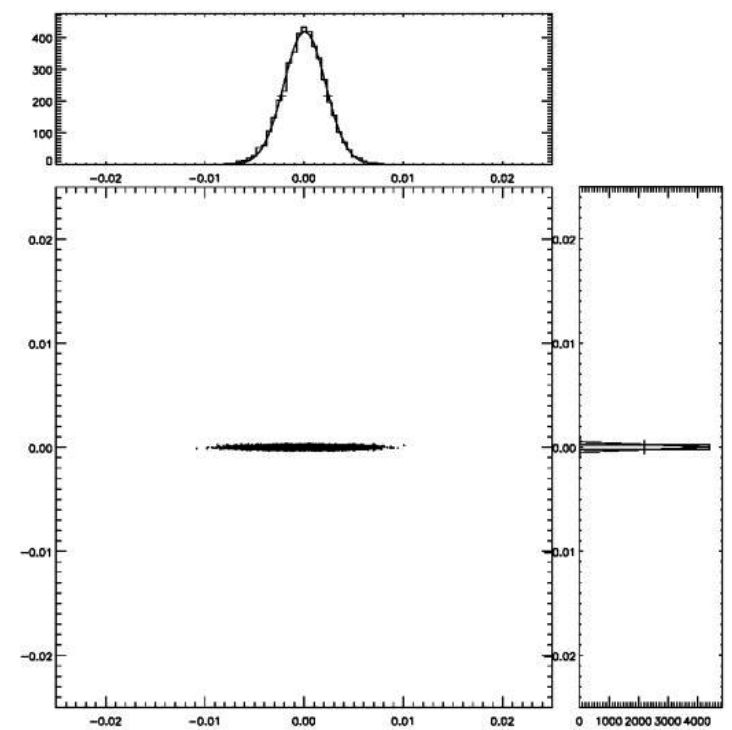

Figure 7. The photon beam at different stages of conditioning. (a) Footprint of the photon beam on the VFM $\left(4.6 \times 238 \mathrm{~mm}^{2} \mathrm{FWHM}(\mathrm{H} \times \mathrm{V})\right)$. (b) Footprint of the photon beam on a screen at the secondary source slits position $\left(2.7 \times 0.01 \mathrm{~mm}^{2} \mathrm{FWHM}(\mathrm{H} \times \mathrm{V})\right)$. (c) Footprint of the photon beam on the HFM $\left(\left(1132 \times 0.08 \mathrm{~mm}^{2} \mathrm{FWHM}(\mathrm{H} \times \mathrm{V})\right)\right.$. $(\mathrm{d})$ Footprint of the photon beam on the $\mu$ VFM $\left(0.8 \times 59.8 \mathrm{~mm}^{2} \mathrm{FWHM}(\mathrm{H} \times \mathrm{V})\right)$. (e) Beam at the sample when $\mu$ VFM mirror is partially defocused on the experimental crystal sample $\left(50 \times 50 \mu \mathrm{m}^{2} \mathrm{FWHM}(\mathrm{H} \times \mathrm{V})\right)$. The vertical object focus for the $\mu \mathrm{VFM}$ was increased to $10 \mathrm{~cm}$ downstream of the crystal. (f) Beam at the sample when $\mu$ VFM mirror is focused on the experimental crystal sample $\left(50 \times 5 \mu \mathrm{m}^{2} \mathrm{FWHM}(\mathrm{H} \times \mathrm{V})\right)$. All figures are in $\mathrm{cm}$. 

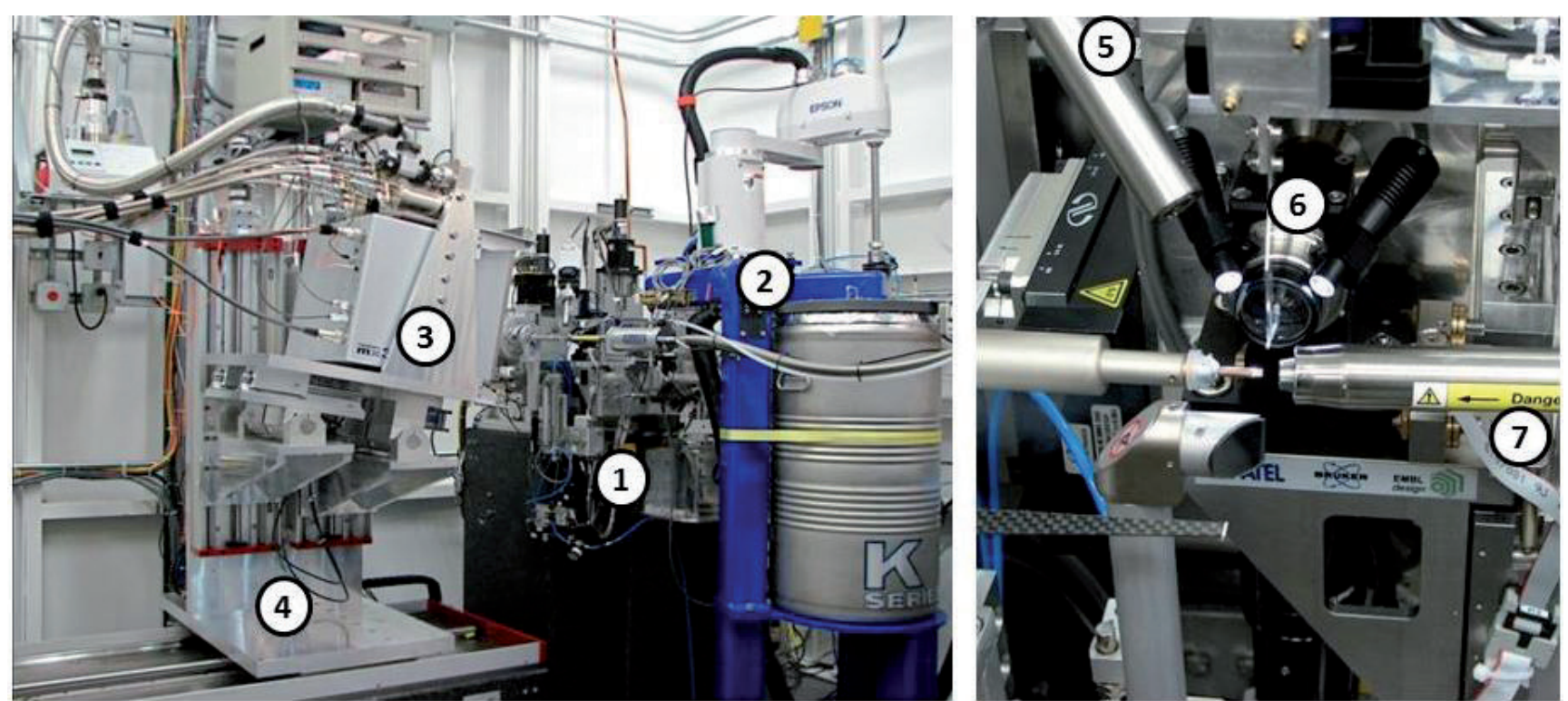

Figure 8. The current picture of the end-station of the 08ID-1 beamline: (1) ACCEL end-station, (2) SAM sample changer, (3) Rayonix MX300 CCD detector, (4) Detector stage, $100-1000 \mathrm{~mm}$ and $0-20^{\circ} 2 \Theta$ swing-out, (5) Xflash fluorescence detector, (6) MAATEL on-axis video microscope.

The first optical component of beamline 08ID-1 is a double crystal monochromator. Its role is to select a narrow band of photon energies required to collect a diffraction pattern. The active components of the DCM are perfect quality silicon crystals. The current 08ID-1 DCM will be modified to accept more power from the new SGU. A substantial amount of power will be absorbed by the upstream diamond filter, which acts as a high-energy pass filter by absorbing the undesired low photon energies $(<5 \mathrm{keV})$. For a $400 \mu \mathrm{m}$ thick diamond filter at the smallest gap of the SGU $(5.2 \mathrm{~mm})$, power density at the DCM's first crystal is calculated to be $26.2 \mathrm{~W} / \mathrm{mm}^{2}$ (Fig. 5). With the beam defining mask standard opening of $280 \times 100 \mu \mathrm{rad}^{2}$ the total power on the first crystal of the DCM will be equal to 298 W [10]. The total power and the associated power density on the first crystal of the DCM are below the maximum of $300 \mathrm{~W}$, acceptable on a side-cooled cryo-crystal $[12,13]$.

The other optical components of the beamline are metal coated silicon mirrors. They are used to remove higher harmonics that pass through the DCM and to focus the photon beam in both directions. The current vertically focusing mirror (VFM) will be replaced with a mirror with adaptive benders to focus the photon beam vertically into a secondary focus. It will be followed by a horizontally focusing mirror (HFM) and then by the micro vertically focusing mirror $(\mu \mathrm{VFM})$ to achieve the desired focus size of $5 \mu \mathrm{m}$ in the vertical direction. The two new mirrors (HFM and $\mu$ VFM) are described in table 2. Light reflectivity off a mirror is a function of photon energy, the coating material of the polished surface, the grazing angle, and the surface roughness. Therefore, to cover the designed photon energy range, two stripes on the mirrors will be required at the grazing angle of $3.9 \mathrm{mrad}$. Rhodium $(\mathrm{Rh})$ will be used for the photon energy range of 5 to $16 \mathrm{keV}$ and iridium (Ir) for the range of $16-20 \mathrm{keV}$ (Fig. 6).

The ray tracing modeling was performed using the program SHADOW [14] with the mirror parameters shown in table 2. SHADOW is a computer program that generates rays simulating the photon source, in this case the SGU, and propagates the rays through the X-ray optics taking into account grazing angles, dimensions, material reflectivities, polarization properties, residual slope errors, surface roughness, and bending radii. The ray-tracing results presented here were obtained for $12 \mathrm{keV} \mathrm{X-rays.} \mathrm{The} \mathrm{photon} \mathrm{beam} \mathrm{"footprint"} \mathrm{on} \mathrm{the} \mathrm{VFM} \mathrm{is}$ shown in figure 7a. The VFM will be an elliptical planar mirror with an adaptive bender. The footprint on the secondary source slits is shown in figure $7 \mathrm{~b}$. The footprints on the HFM and $\mu$ VFM are shown on figure $7 c$ and figure $7 d$, respectively. Figure 7e shows the focused beam at the sample position when the $\mu$ VFM is partially unfocussed and figure $7 \mathrm{f}$ shows the beam when it is focused. Due to the position of the VFM, its slope errors influence significantly the size of the beam at the focus. Therefore, a new mirror with an RMS (root-meansquare) slope error of $0.5 \mu \mathrm{rad}$ and equipped with an adaptive bender will reduce the vertical beam size to $5 \mu \mathrm{m}$. The $\mu \mathrm{VFM}$ will be used to match the vertical beam size with the requested pinhole size in the range of 5 to $50 \mu \mathrm{m}$ by defocusing it accordingly, allowing control of the photon beam to match the crystal size and the control of horizontal divergence. The pinholes are located just upstream of the crystal sample.

\section{END-STATION}

The current end-station of the 08ID-1 beamline is shown in figure 8 . To be able to collect data from micron size crystals, increased stability of the end-station is required with vibrations of the components significantly less than the beam size. Therefore the floor, beamline and end-station components will need to be carefully examined by vibration measurements. It is envisioned that a new 5-axis table will be installed, with additional thermal stability provided by heavy-duty granite. The following components will be located on this table: filters, beam position monitors, $\mu \mathrm{VFM}$, air-bearing based goniometer with a sphere of confusion of less than $1 \mu \mathrm{m}$, exposure box including pinholes, fast shutter and a cryogenic-jet. The end-station will also include a new cryogenic sample changer, with a minimum 400 universal puck sample capability and duty cycle 
of less than $20 \mathrm{~s}$. It will be complemented by a modern single-photon counting detector with an active surface area larger than $300 \mathrm{~mm} \times 300 \mathrm{~mm}^{2}$ and frequency of at least $20 \mathrm{~Hz}$, allowing shutter-less operation. In-situ room-temperature crystal screening will also be possible. It will allow 96-well plates to be screened using a $50 \mu \mathrm{m}$ beam.

\section{CONCLUDING REMARKS}

The Canadian macromolecular crystallographic community supported the idea of upgrading the CMCF 08ID-1 beamline with micro-beam capability. The new powerful undulator and an upgrade of the X-ray optics will allow delivery of photon flux of $>10^{11} \mathrm{ph} / \mathrm{s}$ into a $5 \mu \mathrm{m}$ sample at a photon energy of $12 \mathrm{keV}$. The new fast X-ray detector will allow shutter-less operation, and the new faster sample changer will facilitate room-temperature in-situ experiments. The SHADOW simulations were performed as the first stage of the upgrade of the CMCF 08ID-1 beamline.

\section{REFERENCES}

1. Dauter Z, Jaskolski M, Wlodawer A (2010) Impact of synchrotron radiation on macromolecular crystallography: A personal view. J Synchrotron Radiat 17: 433-444

2. Grochulski P, Fodje M, Labiuk S, Gorin J, Janzen K, Berg R (2012) Canadian macromolecular crystallography facility: a suite of fully automated beamlines. Journal of Structural and Functional Genomics 13: 49-55

3. Grochulski P, Fodje M, Gorin J, Labiuk S, Berg R (2011). Beamline 08ID-1, the prime beamline of the Canadian Macromolecular Crystallography Facility. J Synchrotron Radiat 18: 681-684
4. Smith J, Fischetti RF, Yamamoto M (2012) Micro-crystallography edge. Curr Opin Struct Biol 22: 602-612

5. Owen RL, Juanhuix J, Fuchs M (2016) Current advances in synchrotron radiation instrumentation for MX experiments. Arch Biochem Biophys 602: 21-31

6. Fischetti RF, Yoder D, Xu S, Makarov O, Ogata C \& Smith JL (2013) Predicted optical performance of the GM/CA@APS micro-focus beamline. J Physics: Conference Series 425: 012006

7. Evans G, Alianelli L, Burt M, Wagner A, Sawhney KJS (2007) Diamond beamline I24 a flexible instrument for macromolecular micro-crystallography. AIP Conf Proc 879: 836-839

8. Hirata K, Kawano Y, Ueno G, Hashimoto K, Murakami H, Hasegawa K, Hikima T, Kumasaka T, Yamamoto M (2013) Achievement of protein micro-crystallography at SPring-8 beamline BL32XU. J Physics: Conference Series 425012002

9. Flot D, Mairs T, Giraud T, Guijarro M, Lesourd M, Rey V, van Brussel D, Morawe C, Borel C, Hignette O, Chavanne J, Nurizzo D, McSweeney S, Mitchell E (2010) The ID23-2 structural biology microfocus beamline at the ESRF. J Synchrotron Radiat 17: 107-111

10. SRCALC, Reininger R, Argonne National Laboratory, X-ray Science Division, rreininger@aps.anl.gov

11. Chubar O, Elleaume P, Synchrotron Radiation Workshop (SRW), http://www.esrf.eu/Accelerators/Groups/InsertionDevices/Software/SRW

12. Chumakov A, Rüffer R, Leupold O, Celse J-P, Martel K, Rossat M, Lee W-K (2004) Performance of a silicon monochromator under high heat load. J Synchrotron Radiat 11: 132-141

13. Chumakov A, Sergeev I, Celse JP, Rüffer R, Lesourd M, Zhang L, Sánchez del Río M (2014) Performance of a silicon monochromator under high heat load. J. Synchrotron Radiat 21: 315-325

14. Sanchez del Rio M, Canestran N, Jian F, Cerrina F (2011) SHADOW3: A new version of the synchrotron $\mathrm{X}$-ray optics modelling package. J Synchrotron Radiat 18: 708-716

\title{
Projektowanie synchrotronowej mikrowiązki dla krystalografii białkowej
}

\author{
Paweł Grochulski ${ }^{1,2,}$, , Mirosław Cygler ${ }^{3}$, Brian Yates $^{1}$
}

${ }^{1}$ Canadian Light Source Inc., 44 Innovation Boulevard, Saskatoon, SK S7N 2V3, Canada ${ }^{2}$ College of Pharmacy and Nutrition, University of Saskatchewan, SK S7N 5C9, Canada

${ }^{3}$ Department of Biochemistry, University of Saskatchewan, Saskatoon, SK S7N 5E5, Canada

e-mail: pawel.grochulski@lightsource.ca

Słowa kluczowe: promieniowanie synchrotronowe, biologia strukturalna, optyka rentgenowska, oprzyrządowanie synchrotronowe, wiązka rentgenowska dla krystalografii białek

Pracę tę dedykujemy Alexandrowi Wlodawerowi na Jego siedemdziesiąte urodziny.

\section{STRESZCZENIE}

Krystalograficzna wiązka 08ID-1, która jest jedną z dwóch wiązek tworzących "Canadian Macromolecular Crystallography Facility" (CMCF) zlokalizowanych w ośrodku synchrotronowym Canadian Light Source (CLS), była zaprojektowana ponad trzynaście lat temu. Od 2006 roku pomiary wykonywane w CMCF zaowocowały ponad 400 pracami opublikowanymi $w$ wysoko notowanych czasopismach naukowych oraz depozytami ok. 750 struktur białek w PDB. Krystalografia białek jest podstawowym narzędziem biologii strukturalnej. Dotąd jednak tylko niewielki ułamek z około 30,000 białek kodowanych przez genom człowieka zbadano strukturalnie z uwagi na ogromne trudności z syntezą i krystalizacją tych białek. Ponadto białka membranowe i duże kompleksy białek, które są zaangażowane w ważne procesy biologiczne, są również bardzo trudne w krystalizacji, a ich kryształy, jeśli uda się je otrzymać, zwykle słabo rozpraszają promieniowanie rentgenowskie. Dlatego konieczna była modernizacja wiązki 08ID-1 - aby umożliwić pomiary kryształów mniejszych niż 5 $\mu$ m. Ponieważ synchrotron CLS ma stosunkowo wysoką emitancję (18 nm-rad), jedynym sposobem zwiększenia strumienia fotonów padającego na krysztal, bez zbytniego powiększenia rozbieżności wiązki, jest zastosowanie dłuższego niż obecnie undulatora (3.82 m). Nowy undulator wymagał modernizacji całej optyki rentgenowskiej. Ważnym elementem projektowania nowej wiązki była komputerowa symulacja propagacji promieniowania. Wyniki tej symulacji przedstawione są w niniejszej publikacji. Po modernizacji, wiązka naturalnie zogniskowana na krysztale będzie miała strumień $>10^{13}$ fotonów/s i wymiar $50 \times 5 \mu \mathrm{m}^{2}$. Dodatkowe szczeliny pozwolą zmniejszyć średnicę wiązki do $5 \times 5 \mu \mathrm{m}^{2}$ przy strumieniu fotonów $>10^{11}$ fotonów/s. Stacja końcowa tej wiązki będzie wyposażona w robot zdolny pomieścić co najmniej 400 kryształów i zmienić kryształ w ciągu $20 \mathrm{~s}$, oraz w nowoczesny detektor o powierzchni czynnej nie mniejszej niż $300 \times 300 \mathrm{~mm}^{2}$, pozwalający na odczyt danych z częstotliwością nie mniejszą niż $20 \mathrm{~Hz}$. Taki detektor daje możliwość pomiaru ciagłego, bez zamykania migawki wiązki, co zmniejsza nie tylko czas pomiarów, ale nade wszystko zmniejsza błędy związane z synchronizacją migawki z goniostatem i detektorem. Będzie też możliwość badania kryształów bezpośrednio w kroplach krystalizacyjnych $\mathrm{w}$ temperaturze pokojowej. 